\title{
Poszukiwanie prawdy jako wspólna przestrzeń pracy nauczyciela akademickiego i studenta pedagogiki
}

\section{Wprowadzenie}

Celem opracowania jest ukazanie dróg poszukiwania prawdy w pracy akademickiej, a tym samym przedstawienie obszarów urzeczywistniania tej ważnej, priorytetowej wartości w pracy akademickiej. Chodzi głównie o ukazanie integracji zadań dwóch podmiotów: nauczyciela akademickiego i studenta pedagogiki na płaszczyźnie urzeczywistniania prawdy: jej poszukiwania, odkrywania, głoszenia.

\section{Prawda - zarys zagadnienia}

Rozpatrując zagadnienie prawdy w kształceniu nauczycieli zasadne staje się nawiązanie do teorii prawdy. Wśród nich wyróżnia się m.in.:

- teorię korespondencyjną - zgodność myśli, poznania intelektu z bytem, rzeczywistością, stanem rzeczy (Arystoteles, Tomasz z Akwinu);

- koherencyjną - opierającą się na wewnętrznej spójności teorii i twierdzeń (C. Hempel);

- pragamatyczną - odwołującą się do użyteczności i praktycznej sprawdzalności sądów, przekonań czy teorii (W. James, J. Dewey); 
- semantyczną - bazującą na związku znaków danego języka z oznaczoną przez znaki rzeczywistością (A. Torski) ${ }^{1}$.

Wyróżnia się klasyczne i nieklasyczne teorie prawdy. Teorie klasyczne uwzględniają teorię korespondencyjną, nieklasyczne podważają możliwości doświadczenia intelektu z rzeczywistością. W teoriach klasycznych prawdzie przypisuje się fundamentalne znaczenie i rozróżnia się jej wielorakie aspekty.

W teoriach nieklasycznych występuje marginalizowanie prawdy, sprowadzanie jej do zabiegów językowych ${ }^{2}$. Tomasz Duma zwraca uwagę, że „całościowe ujęcie prawdy wymaga uwzględnienia jej aspektu metafizycznego, poznawczego, logicznego, co umożliwia w zasadzie, jedynie korespondencyjna teoria prawdy"3. W Słowniku współczesnego języka polskiego pojęcie prawdy definiowane jest jako: „idea, zasada, teza, uważana powszechnie za niepodważalną, wynikającą z ludzkiego doświadczenia albo dowiedziona naukowo"4.

Powyższa definicja wskazuje na dwa źródła prawdy:

- badania naukowe;

- doświadczenie życiowe człowieka.

W pracy nauczyciela akademickiego/nauczyciela na każdym etapie kształcenia obydwa źródła mają istotne znaczenie i obydwie kategorie prawdy powinny być ze sobą integrowane.

Prawda stanowi element strukturalny triady uniwersalnych wartości. Stanowi istotną cechę człowieka - tylko człowiek jest zdolny do poszukiwania prawdy, jej odkrywania i głoszenia. Pełni wiele funkcji, w tym stanowi kryterium wartości, poznawania rzeczy, faktów, zjawisk, procesów, kryterium postępowania, czynnik warunkujący rozumienie człowieka - jego funkcjonowania i działania. Jak podkreśla Duma „dotyczy uniwersalnych właściwości bytu oraz kwalifikacji wyrażających wartości poznania, wypowiedzi i norm postępowania, warunkuje rozumienie bytu ludzkiego i jego działania"

1 T. Duma, Prawda, [w:] K. Chałas, A. Maj (red.) Encyklopedia aksjologii pedagogicznej, Polwen Polskie Wydawnictwo Encyklopedyczne, Radom 2016, s. 868.

2 Ibidem, s. 868.

3 Ibidem.

4 Prawda, [w:] Słownik współczesnego języka polskiego, t. 2, wyd. 2, Reader's Digest Przegląd, Warszawa 2001, s. 142.

5 T. Duma, Encyklopedia aksjologii pedagogicznej..., s. 868. 
Analizując powyższe aspekty prawdy należy podkreślić, że:

- prawda o znaczeniu metafizycznym jest transcendentną właściwością bytu i wyraża przyporządkowanie bytu do intelektu;

- prawda ontologiczna - będąca właściwością wytwarzanej przez intelekt idei - myśli, odznaczającej się wewnętrzną zgodnością.

Prawda logiczna - będąca właściwością wypowiedzi określająca jej stosunek do faktu'

Według Dumy „dopiero powiązanie znaczeń daje pełny obraz prawdy o filozofii, gdzie prawdy poznawcza i logiczna zależne są od prawdy bytu będącej dla nich jedynym kryterium, które znajduje swoje ostateczne uzasadnienie w prawdzie Absolutu"?

Władysław Stróżewski podkreśla, że prawda jest sprawą trudną. $\mathrm{Na}$ jej trudność rzutuje obiektywność, absolutność, bezinteresowność, których wymaga jej dociekanie ${ }^{8}$.

Ta triada warunkuje traktowanie prawdy jako wartości najwyższej. Autor zaznacza, że „Trudność prawdy to przede wszystkim trud jej

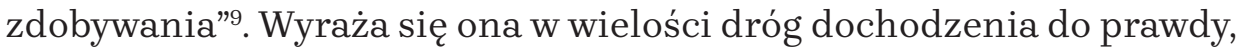
a co się z tym wiąże metod badawczych, bycia wolnym w podejmowaniu decyzji. Z prawdą jest więc związany pluralizm metodologiczny i wolność.

\section{Rysunek 1. Prawda}

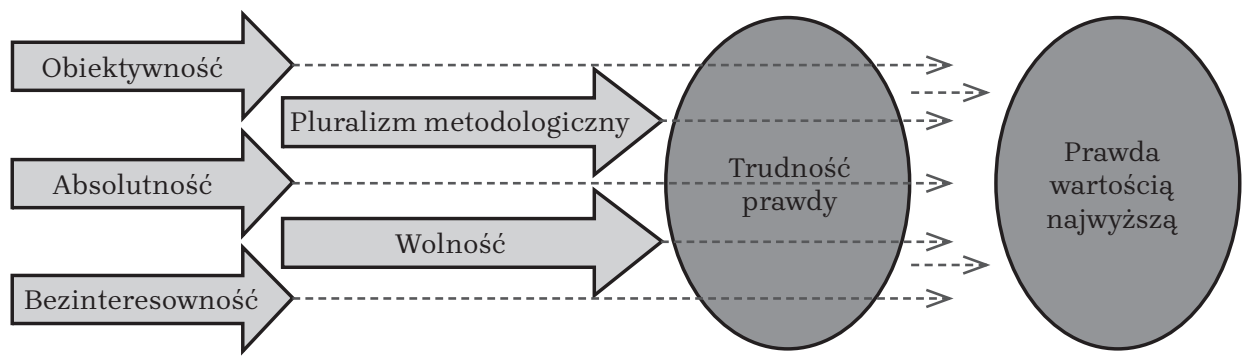

Źródło: opracowanie własne.

\footnotetext{
Ibidem, s. 868-869.

Ibidem, s. 860.

Zob. W. Stróżewski, W kręgu wartości, Wydawnictwo Znak, Kraków 1992, s. 8.

Ibidem, s. 13.
} 
Według W. Stróżewskiego

postulat metodologicznego pluralizmu musi być traktowany jako naczelna idea regulatywna każdej instytucji poświęconej zdobywaniu naukowej prawdy. Istnieje konieczność wstępowania na różne drogi wypróbowywania różnorodnych metod badawczych. Wymaga to z kolei bezwzględnej wolności ich stosowania, wolności podejmowania jednych i odrzucania innych, wolność w osiąganiu sukcesu, ale i wolność w narażaniu się na błąd i porażkę ${ }^{10}$.

Marian Nowak stoi na stanowisku, że:

Prawdy i jej poszukiwania nie możemy wiązać tylko z tradycyjną koncepcją i strategią nauczania i wychowania, lecz w ogóle z sytuacją egzystencjalną człowieka. Człowiek w realistycznym ujęciu jest istotą, która poszukuje prawdy, także tej o swoim własnym celu życia i sensie istnienia. Tej prawdy potrzebują też społeczeństwa $^{11}$.

Jak zauważa M. Nowak, prawda jest wartością osobową (angażuje całego człowieka) i poznawczą, nadającą sens poznaniu zarówno przednaukowemu, jak i naukowemu. Stosuje się tutaj wyjaśnienie, wnioskowanie, eksperymentowanie, przy respektowaniu obiektywizmu naukowego, możliwego w obiektywnym stosunku do przedmiotu nauki, gdzie podmiot nie wnosiłby niczego istotnego do charakterystyki wiedzy naukowej, chociaż pojawiają się zdania łagodzące tego rodzaju stanowiska ${ }^{12}$.

Autor analizując nieklasyczne koncepcje prawdy zaznacza, że ich wielorakość i zróżnicowanie pozwala coraz bardziej odkryć także „podmiotową i subiektywną stronę ludzkiego poznania i tworzonej przez człowieka wiedzy"13.

Podkreśla przy tym ważność tego stanowiska

nie tylko na gruncie wychowania i nauczania, ale w ogóle w życiu współczesnym, gdzie coraz wydatniej narzuca się jeszcze innym wniosek, a mianowicie, że systemy współczesne, często koncentrując się na samej koncepcji, czy na zarysie podstaw badań własnych, chcąc być wierne swoim ideałom, tym samym oddalają się od konkretnego pedagogicznego działania ${ }^{14}$.

\footnotetext{
10 Ibidem.

11 M. Nowak, Koncepcja prawdy a formy myślenia naukowego i badań naukowych, [w:] A. Murawska, I. Kość (red.), Edukacja akademicka wobec prawdy, Wydawnictwo Naukowe Uniwersytetu Szczecińskiego, Szczecin 2010, s. 27.

12 Ibidem, s. 22-23.

13 Ibidem, s. 23.

14 Ibidem, s. 26-27.
} 
Stąd wiedzie droga do wyizolowania się z rzeczywistości i pozostawanie w sferze możliwości ${ }^{15}$.

Marian Nowak stoi na stanowisku potrzeby „powrotu do pewnych kryteriów, norm i zasad - powrotu do klasycznej koncepcji wychowania i prawdy czy nauki, ale $z$ uwzględnieniem także nowych propozycji i nowych stanowisk w kwestii prawdy. W ten też sposób problemtyzowane jest klasyczne rozumienie prawdy uważanej za główny cel nauki. Racjonalność nauki jawi się jako dopełniona przez racjonalność aksjologiczną i przez własne doświadczenie życiowe, czy poznawcze" ${ }^{16}$.

Droga dochodzenia do prawdy, jest trudnym procesem, składającym się z kilku etapów i wymagającym dużego wysiłku, predyspozycji osobowościowych, uwarunkowań zewnętrznych.

\section{Wartość i miejsce prawdy w kształceniu akademickim}

Prawda towarzyszy człowiekowi od zarania ludzkości. Dotyczy ona wszystkich ludzi w całokształcie ich życia. Wpisana jest w naturę człowieka w jego postawy antropologiczne, w życie osobiste i społeczne. Można ją odnieść do każdej sfery jego funkcjonowania: biologicznej, psychicznej/poznawczej, społecznej, kulturowej i światopoglądowej. Wpisuje się w etos akademicki, jako podstawowa wartość. Posiada kluczowe miejsca w misji i powstaniu uniwersytetu, pełniąc funkcję „gwiazdy zarannej” dla tych, którzy podejmują wędrówkę pracy akademickiej. Wartość prawdy „wpisuje się” i integruje pozostałe funkcje uniwersytetu: dydaktyczną, wychowawczą, kulturotwórczą. „Wszystkie inne funkcje uniwersytetu - podkreśla W. Stróżewski - dydaktyczna, wychowawcza, kulturotwórcza itd. są albo konsekwencją owego zadania podstawowego albo się z nim wiążą. To dwojakie zadanie uniwersytetu nie tylko zaprzecza jego jedności, ale je wręcz konstytuuje, jako najbardziej fundamentalną cechę tej instytucji" ${ }^{17}$. W odkrywaniu prawdy ważną kwestią jest poznanie wiedzy prawdziwej, bez zafałszowań wiedzy integralnej, holistycznej, pozwalającej na pełniejsze poznanie i rozumienie siebie oraz otaczającej rzeczywistości w jej różnorodnych wymiarach: przyrodniczym, społeczno-kulturowym,

\footnotetext{
Ibidem, s. 27.

Ibidem.

W. Stróżewski, W kręgu wartości..., s. 8.
} 
ekonomiczno-gospodarczym, religijnym. Poszukiwanie, odkrywanie prawdy, jej głoszenie i służba prawdzie stanowią podstawę dostojeństwa uniwersytetu, którym jest przyjęcie prawdy, jako wartości autotelicznej i uczynienie $z$ niej podstawy badań naukowych, kształcenia akademickiego i pełnienia przez uniwersytet służby społecznej oraz kulturotwórczej. W tej triadzie prawda stanowi czynnik generujący i dynamizujący aktywność podmiotów: nauczycieli akademickich i studentów.

Naczelnym celem pracy nauczyciela akademickiego jest urzeczywistnianie wartości poznawczych, wśród których prawda zajmuje najważniejsze miejsce w ich hierarchii. Jak podkreśla U. Ostrowska „Wartość prawdy sytuuje się u podstaw wszelkich aktów poznawczych nieznających granic ludzkiej myśli (...). Dążenie człowieka do prawdy łączy się z odkrywaniem istoty jego życia, z nadawaniem sensu człowieczej egzystencji, w tym projektowania samego siebie"18.

$\mathrm{Na}$ miejsce funkcje prawdy w kształceniu uniwersyteckim trzeba patrzeć przez pryzmat triady: człowiek - prawda - uniwersytet, którą łączą wzajemne związki i zależności. Na ten związek trzech wyżej wskazanych elementów zwraca uwagę Jan Paweł II.

Instytucje, które - pisze papież - noszą nazwę uniwersytetu (...) głoszą swym istnieniem tą podstawową prawdę o człowieku. O ludzkim poznaniu. Cała rzeczywistość jest zadana człowiekowi pod kątem prawdy. Uniwersytet mówi jednocześnie o szczególnym „zadłużeniu” człowieka wobec całej zróżnicowanej rzeczywistości. Jest to zadłużenie przez prawdę. Człowiek winien jest światu prawdę. Poprzez poznanie prawdy o świecie, rzeczywistości, o Stwórcy i o stworzeniu, człowiek spłaca ten dług a równocześnie urzeczywistnia samego siebie. Usprawiedliwia swoją „rozumność" w całym wszechświecie ${ }^{19}$.

W procesie urzeczywistniania wartości prawdy, każdy doświadcza samego siebie i wartościuje siebie, podejmuje decyzje autokreacyjne i autoformacyjne w perspektywie umocnienia swego człowieczeństwa. Prawda wpisuje się w etos akademicki jako podstawowa wartość.

18 U. Ostrowska, Uczelnia wyższa, jako przestrzeń wartości na drodze do prawdy, [w:] A. Murawska, H. Kość (red.), Edukacja akademicka wobec prawdy, Wydawnictwo Naukowe Uniwersytetu Szczecińskiego, Szczecin 2010, s. 36.

19 Jan Paweł II, Homilia w czasie liturgii słowa skierowanego do środowiska Katolickiego Uniwersytetu Lubelskiego 1987, [w:] Jan Paweł II, Pielgrzymki do Ojczyzny - Przemówienia i homilie, Wydawnictwo Znak, Kraków 2005, s. 404. 
W kształceniu przyszłych nauczycieli zasadne staje się przyjęcie tezy M. Nowaka, że

prawda nie jest jedynie jakimś prostym logicznym porządkiem pomiędzy pojęciami, ani jakimiś jedynie poprawnym użyciem reguł, technik lub narzędzi poznania, lecz o wiele bardziej dotyczy ona ludzkiego sposobu przybliżania się do rzeczywistości, ustosunkowywania się wobec niej i ujmowania jej. Chodzi więc o poznanie jej przez zmysły, rozum, intuicję, uczciwość, działanie, dynamikę, siłę woli²0.

Autor słusznie zauważa, że prawda jest bardzo poważnym i trudnym problemem, o którym ostatecznie decyduje zawsze człowiek ${ }^{21}$.

\section{Rysunek 2. Hierarchiczna struktura etapów prawdy}

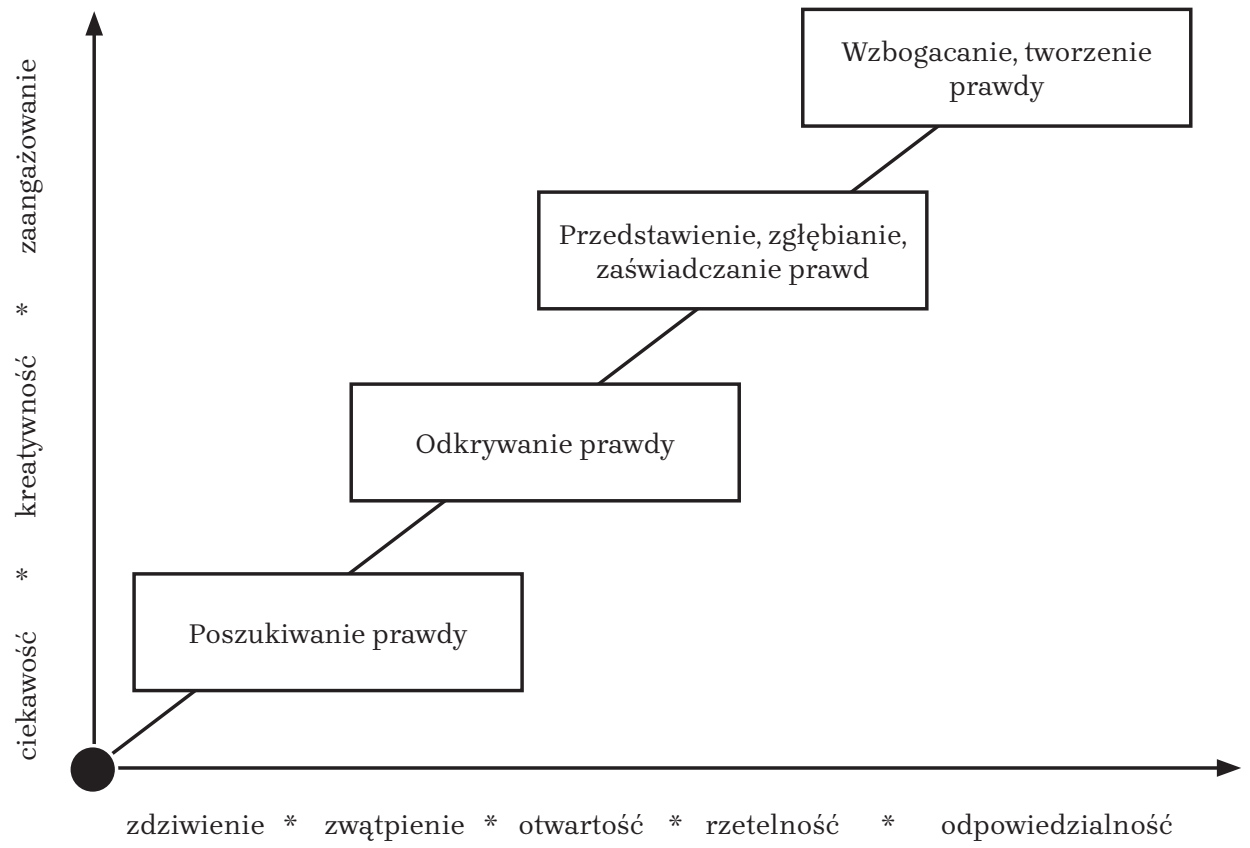

Źródło: opracowanie na podstawie U. Ostrowska, Uczelnia wyższa..., s. 47.

Im większe zaangażowanie nauczyciela/studenta $\mathrm{w}$ poznawanie prawdy, docieranie do rzeczywistości pedagogicznej, tym większe poznawanie siebie, swojego potencjału i szansa odpowiedzi na pytanie

20 M. Nowak, Koncepcja prawdy a formy myślenia naukowego i badań naukowych..., s. 17.

21 Ibidem, s. 18. 
o własne kompetencje, sens pracy pedagogicznej, ale też sens własnego istnienia.

Ważne w tym względzie staje się włączenie przedmiotu i efektów poznania w strukturę nauczycielskiego życia.

Urszula Ostrowska wyróżnia cztery etapy drogi wiodącej do prawdy w przestrzeni edukacji akademickiej. Ujmuje je schematycznie. $\mathrm{Na}$ obu współrzędnych autorka umieściła cechy, postawy, wartości, kompetencje, wśród których na współrzędnej wertykalnej ciekawość, kreatywność, zaangażowanie, a na współrzędnej horyzontalnej: zdziwienie, zwątpienie, otwartość, rzetelność, odpowiedzialność.

Jako punkt wyjścia czyni U. Ostrowska etap/poziom 0 określany etapem/poziomem predykatywnym. Według autorki

zawiera on wszakże zalążki prawdy w postaci przesądów („przedrozumienia”) i w sprzyjających okolicznościach może wychodzić naprzeciw wspinaniu się na etap/poziom wstępny, określany jako:

1) „poszukiwanie prawdy” - (...) jest to sytuowanie się właśnie na wstępnym etapie/poziomie drogi do prawdy, warunkującym sine qua non dochodzenie do kolejnego etapu:

2) „odkrywania prawdy” - na tym etapie nieodzowna jest postawa otwartości (zaznaczona na współrzędnej horyzontalnej), warunkująca wyjście (z „kryjówek” niewiedzy) „ponad”.../,poza”, za sprawą uznawania przekonań za trafne (tzn. zgodne z pewnymi stanami rzeczy) i/lub odrzucenie przekonań nietrafnych oraz poszukiwanie ogólnych cech tych przekonań, co summa summarum umożliwia zdążanie ku kolejnemu etapowi:

3) „przedstawiania, zgłębiania, zaświadczania prawdy” - prezentowanie przesłanek do uzupełnienia i/lub korygowania dotychczasowych zasobów wiedzy oraz zastępowania obowiązujących bardziej doskonałymi teoriami i wreszcie:

4) najważniejszy z etapów/poziomów wymaga zwłaszcza kreatywności, talentu aktywności twórczej, określony został jako „wzbogacenie, tworzenie prawdy” koncentrujący się wokół uznawania nowych odkryć i teorii naukowych ${ }^{22}$.

\section{Obszary prawdy}

Nie ma kształcenia akademickiego/kształcenia szkolnego pełniącego funkcję naukowa, dydaktyczną, wychowawczą, formacyjną, kulturową bez odpowiedzi na pytanie, kim jest człowiek? Prawda o człowieku jest punktem wyjścia w tym względzie. Warunkuje treści oraz strategie, metody, zasady postępowania pedagogicznego. Przyjęcie antropologicznej podstawy rzutuje na aksjosferę kształcenia.

$22 \quad$ Ibidem, s. 48. 
Chodzi tu o prawdę pełną o człowieku, która pozwala go ując holistycznie bez redukcji jego sfer życia i funkcjonowania. Na uwagę w tym względzie zasługuje przyjęcie koncepcji personalistycznej: człowiek jest osobą bytem cielesno-duchowym. Posiada przymioty: godność, rozumność-mądrość, wolność, odpowiedzialność, zdolność do miłości, zdolność do transcendencji. Prawda o sobie łączy się o każdym innym człowieku, co implikuje postawy i zachowania wobec innej osoby i przyjmowanie jej perspektywy w postrzeganiu przez nią sytuacji. Przyjęcie w kształceniu akademickim przyszłych nauczycieli tej koncepcji człowieka pozwala na holistyczne integralne ujęcie osoby nauczyciela akademickiego i jego funkcji, osoby studenta i jego zadań „teraz” i w przyszłej pracy nauczycielskiej; specyfiki dydaktycznej procesu kształcenia.

W strukturze prawdy uniwersyteckiej swe centralne miejsce zajmuje prawda kultury/prawda kulturowa. Implikuje ona określone zadania dla kadry akademickiej i studentów. Strukturę tych zadań tworzą:

- przechowywanie kultury;

- porządkowanie kultury;

- wydobywanie z kultury wartości i ich urzeczywistnianie;

- przekazywanie wartości, utrwalanie, pielęgnowanie, ochrona przed zapomnieniem.

Jak słusznie podkreśla I. Kość „Uniwersytet powinien kulturę nie tylko przechowywać, ale jako jeden z jej depozytariuszy porządkować ją i wydobywać z niej ukryte wartości, nade wszystko jednak, powinien ją przekazywać, utrwalać, chronić od zapomnienia, stać na straży jej przestrzegania, bronić i celebrować" ${ }^{23}$.

Ważnym czynnikiem urzeczywistniania prawdy w kształceniu akademickim jest własna kultura uniwersytetu. Tworzona przez ustalone normy etyczne, preferowane i urzeczywistniane wartości, tradycje, otwartość na teraźniejszą rzeczywistość, perspektywę przyszłości oraz kultura osobista nauczycieli i studentów, rozwiązania organizacyjne. Przez kulturę uniwersytecką tworzony jest stosunek do drugiego człowieka, środowiska społeczno-kulturowego, przyrody, Państwa, Ojczyzny, Boga.

23 I. Kość, Uniwersytet, jako adwokat prawdy, [w:] A. Murawska, I. Kość (red.), Edukacja akademicka..., s. 85. 
Kultura uniwersytetu stanowi istotną płaszczyznę, na której następuje integracja normatywna, kulturowa, komunikacyjna i funkcjonalna nauczycieli i studentów w poszukiwaniu prawdy i służby prawdzie. I zwrotnie to poszukiwanie prawdy na bazie integracji tych dwóch podmiotów buduje kulturę uniwersytetu.

Czwartym obszarem prawdy wspólnie poszukiwanej, odkrywanej jest kultura szkoły - zarówno tej aktualnie funkcjonującej, w której student zdobywa doświadczenie, pedagogicznej, jak również tej przyszłej, w której podejmuje prace i którą będzie tworzył/kreował.

\section{Rysunek 3. Obszary prawdy}

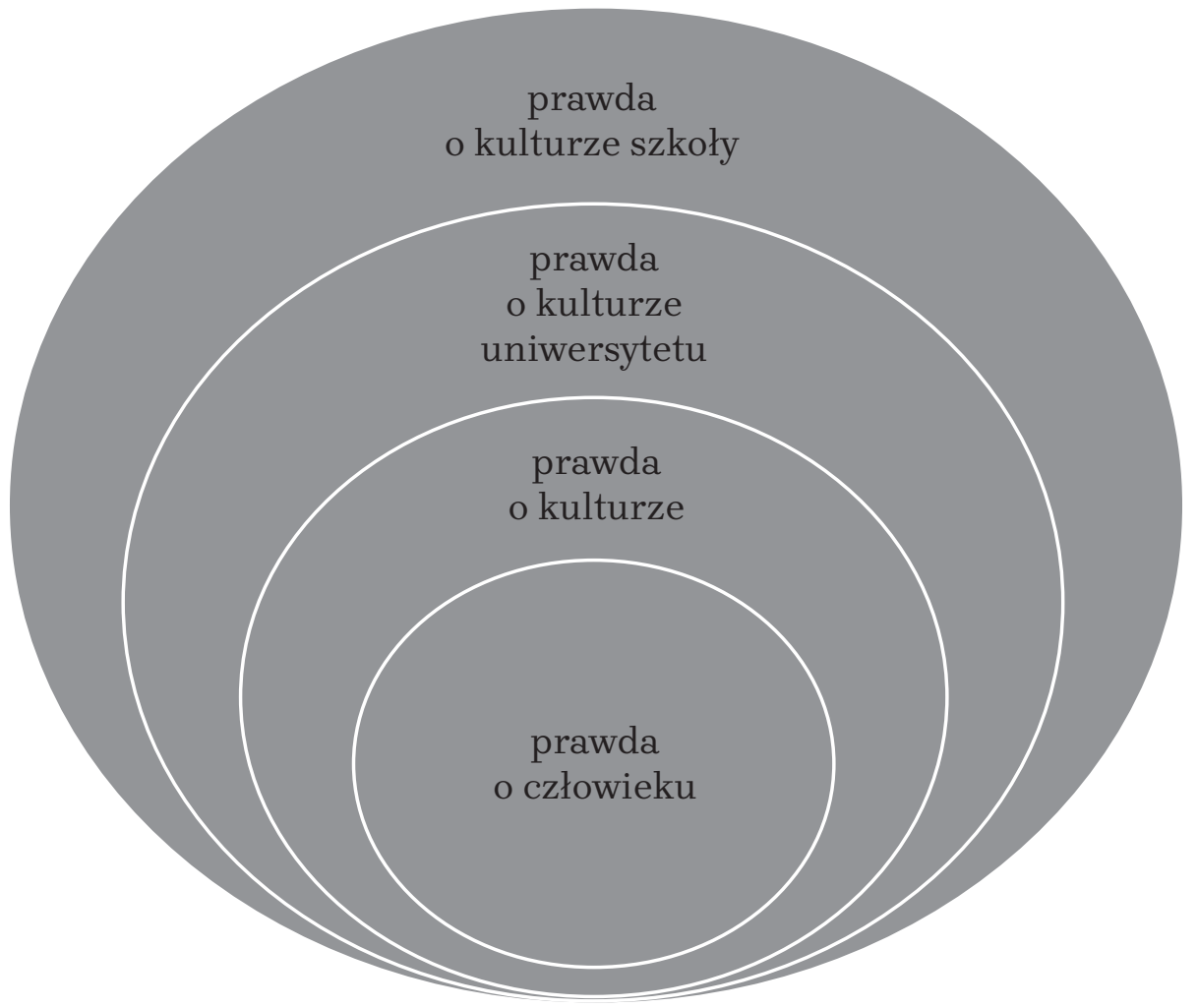

Źródło: opracowanie własne.

Projekt przyszłości/projekt szkoły pożądanej, jej kultura stanowi ogniskową prawd cząstkowych, strukturalnych, do których należy zaliczyć: prawdę o uczniu, nauczycielu szkoły jako organizacji, prawdę 
tkwiącą w poszczególnych przedmiotach nauczania, prawdę o trudnościach, barierach i szansach rozwojowych podmiotów i szkoły jako organizacji. Można też wyróżnić bardziej szczegółowe obszary wspólnego odkrywania prawdy.

- Prawda o człowieku/studencie, uczniu, rodzicach/rodzinie.

- Prawda o szkole w ujęciu historycznym i współczesnym.

- Prawda o misji i zawodzie nauczyciela.

Powstaje pytanie o dydaktyczne dochodzenie do prawdy: o strategie, zasady, metody tak, by dać dobry wzór studentom, jako przyszłym nauczycielom. Należy przy tym podkreślić, że odkrywanie prawdy odbywa się przez uprawianie nauki. Odbywa się na drodze naukowego sposobu dochodzenia do wiedzy prawdziwej, rzetelnej poszerzania jej zakresu, budowania nowych struktur, kontekstów, wymiarów.

Wśród dróg dochodzenia do prawdy wyróżnia się cztery podstawowe:

- za pomocą naturalnego rozumu;

- za pomocą postrzegania zmysłowego;

- za pomocą doświadczenia;

- za pomocą wiary ${ }^{24}$.

Na szczególną uwagę w tym względzie zasługuje integracja nauczania/procesu dydaktycznego $\mathbf{z}$ badawczym. Należy podkreślić, że edukacja w szkole wyższej/akademii/uniwersytecie jest ściśle związana z nauką, która jest źródłem wiedzy - pomnaża ją i wzbogaca. Między dydaktyką akademicką i nauką występuje związek wzajemnych uwarunkowań ${ }^{25}$.

Jak zauważa U. Ostrowska:

dydaktyka akademicka, wprowadzając studentów w naukowy sposób poznawania rzeczywistości, tę wiedzę z założenia inspirująco transportuje, polaryzuje i utrwala, co zgodne jest z wciąż żywą w wyższych uczelniach Humboldowską ideologią, która głosi, że badania naukowe i dydaktyka wspierają się wzajemnie i warunkują ${ }^{26}$.

24 Zob. Jan Paweł II, Encyklika Fides et Ratio, Wydawnictwo Znak, Kraków 1998.

25 Zob. S. Palka, Pedagogika w stanie tworzenia. Kontynuacje, Wydawnictwo Uniwersytetu Jagiellońskiego, Kraków 2003, s. 142.

26 U. Ostrowska, Dylematy z zakresu kształcenia w szkole wyższej w aspekcie kształcenia, [w:] K. Jankowski, B. Sitarska, C. Tkaczuk (red.), Jakość kształcenia w szkole wyższej moda czy konieczność, Wydawnictwo Uczelniane Akademii Podlaskiej, Siedlce 2000, s. 85. 
Strategia ta poprzez inicjujące wzajemnie związki i zależności dydaktyki i badań naukowych stanowi płaszczyznę rozwijania samodzielności poznawczej studentów - przyszłych nauczycieli. Jednym z istotnych warunków poznawczej samodzielności studentów jest zbudowanie w sobie pozytywnej postawy poznawczej, przejawiającej się w samodzielnym przetwarzaniu wiedzy dydaktycznej i krytycznej ich analizie oraz samodzielności badawczej ${ }^{27}$ jako drogi odkrywania prawdy. Ta integracja procesu dydaktycznego $z$ badawczym może obejmować cztery sytuacje:

- nauczanie przez badanie - prowadzenie przez studentów działalności badawczej w ramach nauczanych przedmiotów;

- mikrobadania faktów i zjawisk pedagogicznych przez studentów w ramach nauczanych przedmiotów kształcenia akademickiego, a przez to wzbogacania wiedzy, teoretycznej potwierdzanie jej przez wyniki mikrobadań;

- udział studentów w badaniach nauczyciela akademickiego/ studentów;

- badania indywidualne w ramach seminarium licencjackiego/ magisterskiego ${ }^{28}$.

Priorytetową zasadą w procesie kształcenia przyszłych nauczycieli, jest zasada wspólnotowości w poszukiwaniu, odkrywaniu, głoszeniu prawdy. Budowanie wspólnoty nauczycieli akademickich - studentów, jako zadanie. Cele tej wspólnoty i sposoby jej realizacji muszą wzmacniać możliwości osiągnięcia celu, którym jest prawda. Z drugiej zaś strony wspólnota ta powinna być dla przyszlych nauczycieli mikroszkołą budowania przyszłej wspólnoty nauczyciel uczeń - rodzice.

Jak zauważają D. Pawluk i D. Skowrońska

dążenie, odkrywanie prawdy winno odbywać się zawsze we wspólnocie. Wspólnocie nie tylko samych ludzi nauki, współpracujących ze sobą w ramach różnych dyscyplin akademickich czy też interdyscyplinarnie dla dobra ludzkości, ale również wspólnocie nauczycieli akademickich-badaczy ze studentami. Misja - badania naukowe prowadzące ku prawdzie - to nie tylko samo odkrywanie prawdy poprzez nie, ale również wdrażanie młodych adeptów nauki w istotę i język nauki,

$\overline{27}$ Zob. S. Palka, Pedagogika w stanie tworzenia. Kontynuacje..., s. 142.

28 Zob. K. Chałas, Dydaktyka akademicka w uniwersytecie katolickim, t. 1: Dydaktyka zaangażowana z doświadczeń Katedry Dydaktyki i Edukacji Szkolnej KUL, Wydawnictwo KUL, Lublin 2019, s. 136. 
myślenie merytoryczne i metodologiczne, niezbędne dla wspólnych i samodzielnych badań, pozwalające uniwersytetowi zachować ciągłość swego istnienia poprzez dopływ badaczy ${ }^{29}$.

Prawda stanowi ogniwo łączące prowadzenie badań/uprawianie nauki z funkcją dydaktyczną. Ten związek ukazuje poniższy schemat.

\section{Schemat 1. Związek nauki z działaniami dydaktycznymi}

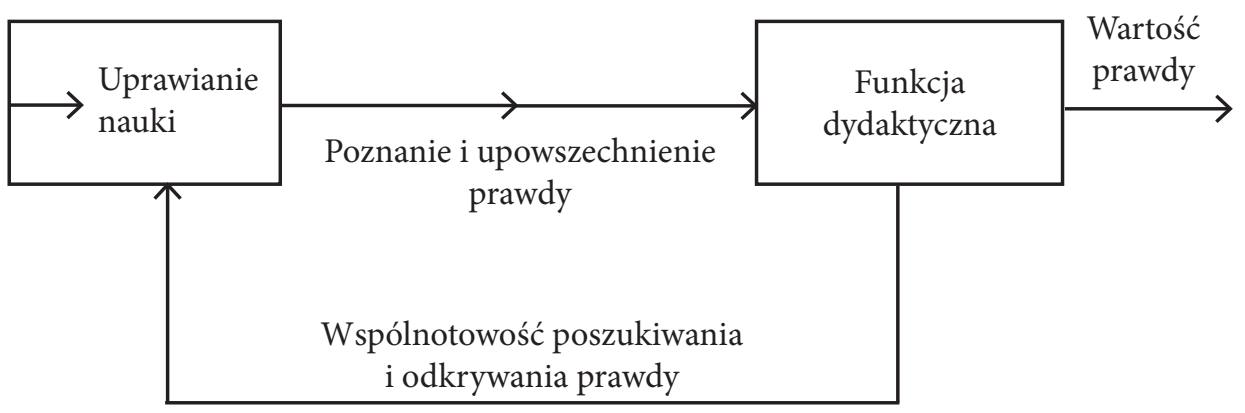

Źródło: opracowanie własne.

W ten sposób budowana jest wspólnota: nauczyciel akademicki student, budowana w drodze do prawdy.

Witold Starnawski formułuje zasady określające rolę prawdy we wspólnocie:

- „Każde działanie podejmowane ze względu na prawdę i obiektywnie prawdziwe służy budowaniu wspólnoty.

- Wszelkie działania, które odbierają prawdzie jej wartość transcendentną bądź też rozmyślnie odrzucają czy deformują prawdę - podważają i niszczą wspólnotę ${ }^{30}$.

Poszukiwanie prawdy i dochodzenie do prawdy dokonuje się w relacjach interpersonalnych, wyrażonych przez dar z siebie, wierność sobie i drugiemu człowiekowi oraz zaufanie.

29 D. Pawluk, D. Skowrońska, Prawda - misja i wyzwanie dla współczesnego uniwersytetu, [w:] Edukacja akademicka wobec prawdy..., s. 102.

30 W. Starnawski, Prawda podstawą wspólnoty, Wydawnictwo Salezjańskie, Warszawa 2005, s. 193. 
Powstaje pytanie o dydaktyczne dochodzenie do prawdy, o metodyczne metody poznawania, głoszenia prawdy. Są one uwarunkowane obszarami wiedzy, dziedzinami i dyscyplinami naukowymi.

Prawda wyłania się „w procesie poznawania, doświadczania, opisywania rzeczywistości, w toku przetwarzania informacji w wiedzę"31.

Urszula Ostrowska podkreśla, że:

Istotną rolę w edukacji akademickiej na drodze dociekania prawdy/dochodzenia do prawdziwości głoszonej wiedzy niewątpliwie pełni organizowanie dysput naukowych, dialogu, dyskusji, dyskursu - poddawanie krytyce i argumentacji przetwarzanych wyników badań. Czyli inaczej rzecz ujmując - chodzi tu o niekończące się poszukiwanie prawdy w jej nieskończoności, za sprawą pytań i odpowiedzi zawierających sądy i argumenty."32

\section{Odkrywanie prawdy odbywa się przez uprawianie nauki.}

Odbywa się ona na drodze naukowego sposobu dochodzenia do wiedzy prawdziwej, rzetelnej, poszerzenie jej zakresu, budowania nowych struktur, kontekstów, wymiarów. Na szczególną uwagę w tym względzie zasługuje integracja nauczania/ procesu dydaktycznego z badawczym ${ }^{33}$.

Droga do prawdy wiedzie przez dysputy naukowe, dyskusje, swobodną krytykę dorobku myśli naukowej, efektów twórczości, drogi dochodzenia do nich i wykorzystywanych metod w świetle poszanowania prawa naturalnego, poszanowania godności osobowej.

Jedną z ważnych dróg dochodzenia do prawdy w kształceniu akademickim studentów pedagogiki, przyszłych nauczycieli (i nie tylko) jest metoda dialogu.

Jak zauważa Jerzy Milewski metoda ta „pozwala obu stronom dialogu dochodzić ze zrozumieniem do prawdy obiektywnej"34.

Metoda dialogu znajduje swe usytuowanie w pedagogice dialogu. Jej twórcą jest Janusz Tarnowski. Autor wyróżnia trzy formy dialogu: metodę, proces i postawę. Według niego:

\footnotetext{
31 Ibidem, s. 39.

32 Ibidem.

33 Zob. D. Pawluk, D. Skowrońska, Prawda - misja i wyzwanie dla współczesnego uniwersytetu [w:] Edukacja akademicka wobec prawdy...., s. 99; zob. także: K. Chałas, Dydaktyka akademicka w uniwersytecie katolickim, Wydawnictwo KUL, Lublin 2019.

34 J. Milewski, Prawda w metodzie dialogu stosowanej przez nauczyciela akademickiego, [w:] Edukacja akademicka wobec prawdy..., s. 144.
} 
Metoda dialogu jest to sposób komunikacji, w której podmioty dążą do wzajemnego zrozumienia, zbliżania się i współdziałania (wzajemnego w miarę możliwości). Proces dialogu zachodzi natomiast wtedy, gdy chociażby jeden z elementów zawartych w metodzie został urzeczywistniony. (...) Proces dialogowy może zacząć się od któregokolwiek z elementów: poznawczego, emocjonalnego, lub prakseologicznego i stopniowo zmierzać (lub nie) do ogarnięcia stref pozostałych. Natomiast postawa dialogu to gotowość do otwierania się na rozumienie, zbliżanie się i współdziałanie (w miarę możliwości) w stosunku do otoczenia ${ }^{35}$.

Badacz wyodrębnia trzy rodzaje dialogu: rzeczowy, personalny, egzystencjalny.

Przedmiotem dialogu rzeczowego jest poznanie rzeczywistości, celem natomiast poznanie wartości Prawdy.

Dialog personalny występuje wówczas gdy w relacji interpersonalnej z drugim człowiekiem odkrywamy swoje wnętrze, w którym tkwią tajemnice, przeświadczenia, uczucia, pragnienia „serca”. U podstaw dialogu egzystencjalnego jest bezinteresowny dar siebie drugiej osobie przez urzeczywistnianie wartości miłości ${ }^{36}$.

Podstawowymi warunkami dialogu rzeczowego jest dialog personalny i egzystencjalny. Te dwie kategorie dialogu stanowią nośnik poszanowania godności, podmiotowości, wolności, zaufania, odpowiedzialności, przyjaźni, wzajemnej służby, wzajemnego zrozumienia, przyjęcia daru osoby, zachwytu nad Prawdą. Powyżej wskazane elementy stanowią potencjał aksjologiczny dla dialogu rzeczowego.

Jerzy Milewski zwraca uwagę, że

dialog rzeczowy jest związany z wzajemnym zrozumieniem, zbliżaniem się i współdziałaniem nauczyciela akademickiego i studenta, w którym celem nadrzędnym jest poznanie prawdy obiektywnej o danej rzeczywistości społecznej i osobowej człowieka (...) w dialogu chodzi o doprowadzenie do współdziałania, w dochodzeniu do prawdy określonej rzeczywistości i przyjęcia wspólnego stanowiska w celu dalszego poznania czy realizowania tej prawdy ${ }^{37}$.

W dialogu następuje wymiana myśli, wzajemne stawianie pytań, wymiana informacji i sposobu ich rozumienia, zajęcie stanowiska, podjęcie decyzji, argumentacji $i^{38}$.

\footnotetext{
Za: ibidem, s. 45.

36 Por. J. Tarnowski, Jak wychowywać?, Wydawnictwo ATK, Warszawa 1993, s. 116-117.

37 J. Milewski, Prawda w metodzie..., s. 146.

38 Zob. ibidem, s. 147.
} 
Zdaniem J. Milewskiego, doskonalenie metody dialogu stanowi sposób „odkrywania prawdy, jak i sposób kształtowania umiejętności myślenia w kategoriach prawdy, która gdy zostanie ujawniona «broni się sama»" ${ }^{39}$.

Dialog w kontekście prawdy obiektywnej wyznacza nowe perspektywy rozwoju studenta w kierunku wartości prawdy.

Tę perspektywę tworzą:

- poszanowanie prawdy;

- rozumienie jej funkcji w życiu człowieka i wspólnot, w których żyje i funkcjonuje;

- akceptacja prawdy jako wartości;

- urzeczywistnianie prawdy;

- wartościowanie siebie jako człowieka prawdomównego, żyjącego prawdą, służącego prawdzie;

- animacja innych do życia prawdą.

W kontekście dróg dochodzenia do prawdy i holistycznego jej ujęcia oraz uwzględnienia podstaw antropologicznych, w kształceniu przyszłych nauczycieli ważną kwestią jest dobór treści z wielu dyscyplin naukowych: filozofii, teologii, psychologii, socjologii, etyki, organizacji i zarządzania, ekonomii, historii, aksjologii.

Podstawowym zadaniem jest integracja tych treści w większą integralną całość oraz badań, które są charakterystyczne dla poszczególnych dziedzin. W ten sposób stwarzana jest szansa holistycznego ujęcia faktów, zjawisk, procesów pedagogicznych o charakterze teoretycznym i praktycznym; krytycznego namysłu nad nimi.

Droga do prawdy wiedzie poprzez poznawanie faktów, rzeczy, zjawisk, procesów, integrowanie, strukturyzowanie i włączanie we własny zasób wiedzy ${ }^{40}$.

$\overline{39}$ Ibidem, s. 144.

40 A. Rogalska-Morasińska, Poszukiwanie prawdy o człowieku poprzez edukację międzykulturowa. Ku profesjonalizacji zawodu nauczyciela, „Pedagogika Szkoły Wyższej" 2010, nr 32, s. 48-49. 


\section{Uzdalnianie do przyjęcia prawdy jako zadanie nauczyciela akademickiego i studenta/przyszłego nauczyciela}

W kontekście tytułu podrozdziału pozostaje podstawowe pytanie: w jaki sposób nauczyciel akademicki powinien/może uzdalniać studentów do przyjęcia prawdy tak, by w przyszłości, jako nauczyciele uzdalniali swoich uczniów.

Poszukując odpowiedzi można zakreślić pewne kręgi zadań. Pierwszy, obejmuje rozwijanie zdolności poznawczych. Wiąże się z rozwijaniem ciekawości badawczej oraz kultury intelektualnej.

Drugi krąg zadań obejmuje rozwijanie postawy twórczej i uczuciowego zaangażowania na rzecz wartości prawdy, rozmiłowania w prawdzie.

Trzeci obszar zadań obejmuje aspekt dydaktyczny, który można zawrzeć we wskazaniu; nie podawać lecz odkrywać wspólnie prawdę.

Czwartym obszarem zadań jest dawanie świadectwa prawdzie.

Ważnym zadaniem nauczyciela akademickiego jest doprowadzenie studentów do odkrycia własnej zdolności poznania prawdy oraz rozbudzenia głębokiej potrzeby przeradzającej się w tęsknotę za najgłębszym i ostatecznym sensem istnienia ${ }^{41}$. Wiąże się to $\mathrm{z}$ rozwijaniem ich pamięci, wyobraźni, myślenia i inspirowania do zdobywania wiedzy oraz rozwijania mądrości. Na szczególną uwagę zasługuje integrowanie wiedzy i mądrości. „Chodzi o to, by poszukiwać wiedzy, odkrywać prawdę, nie tracąc nigdy z oczu horyzontu mądrościowego, w którym obok zdobyczy naukowych i technicznych dołączają się także wartości filozoficzne i etyczne, będące charakterystycznym i nieodzownym wyrazem tożsamości osoby ludzkiej"².

Służba prawdzie jest priorytetowym zadaniem nauczycieli akademickich. Wyraża się w permanentnym poszukiwaniu prawdy, odkrywaniu, głoszeniu prawdy w życiu, w prawdzie i animowaniu innych do podjęcia tego procesu.

41 Zob. Jan Paweł II, Fides et Ratio..., nr 102, s. 153.

42 Ibidem, nr 106, s. 158. 


\section{Rysunek 4. Kręgi zadań nauczyciela w procesie uzdalniania studenta do przyjęcia prawdy}

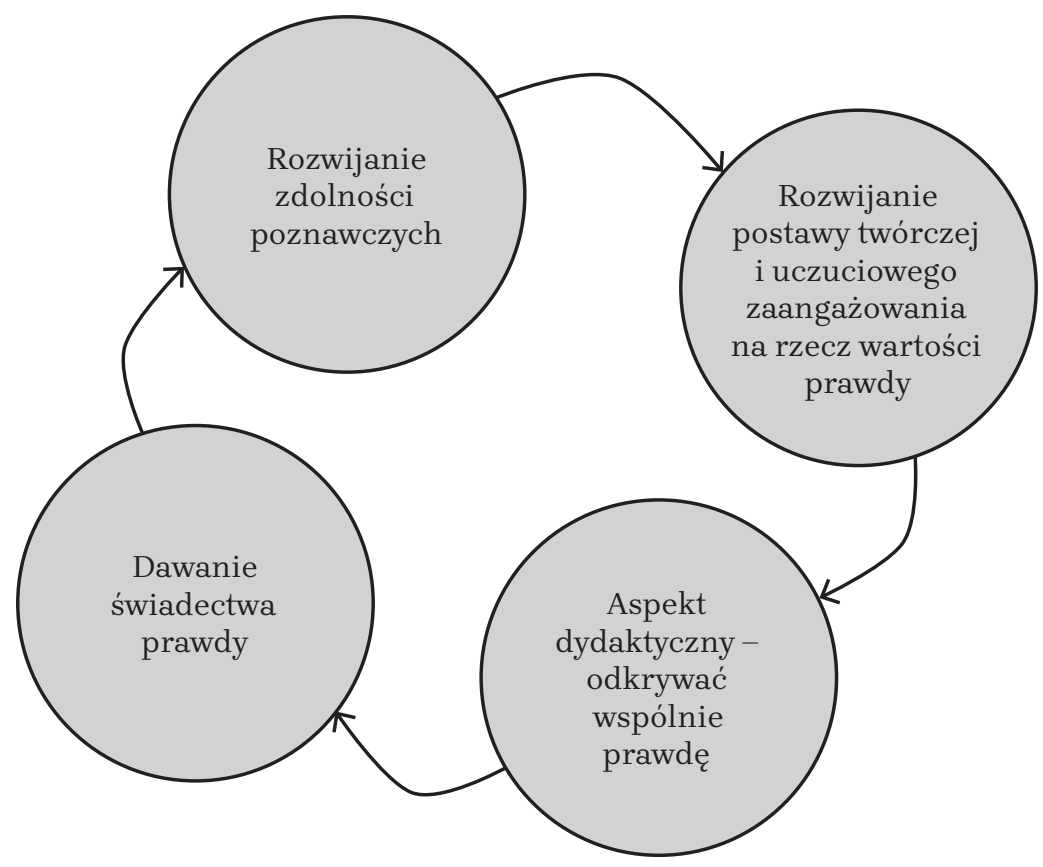

Źródło: opracowanie własne.

Pierwszym krokiem nauczyciela akademickiego kształcącego przyszłych nauczycieli jest pragnienie prawdy: prawdy o sobie, prawdy o studentach, prawdy o rozwoju kultury szkoły, jej przemianach i uwarunkowaniach, prawdy o skuteczności oddziaływań wychowawczo-dydaktycznych. To pragnienie prawdy musi stanowić nieodłączny element pracy akademickiej. Stanowi ono pierwszy nieodzowny warunek służby prawdzie.

Służbę prawdzie, jako podstawowy cel i zadanie uniwersyteckiej wspólnoty uczonych i uczniów, profesorów i studentów, przedstawicieli różnych pokoleń, podkreślał Jan Paweł II. Wypełnianie tego zadania traktował jako podstawę kształtowania człowieka. W tym procesie służby prawdzie szczególną funkcję przypisywał miłości ${ }^{43}$.

43 Jan Paweł II, Przemówienie do przedstawicieli nauki, [w:] Jan Paweł II, Pielgrzymki..., s. 394. 
Służąc prawdzie z miłości do prawdy i do tych, którym ją przekazujemy, budujemy wspólnotę ludzi wolnych w prawdzie, tworzymy wspólnotę ludzi zjednoczonych miłością do prawdy i miłością wzajemną w prawdzie, wspólnotę ludzi, dla których miłość prawdy stanowi zasadę jednoczącej ich więzi ${ }^{44}$.

Prawdę poznajemy poprzez uprawianie nauki. Rzetelne prowadzenie badań naukowych pozwala rozpoznawać błędy, półprawdy, fałsze.

Jednym z istotnych warunków służby prawdzie jest profesjonalizm. Jak podkreśla A.J. Sowiński:

Relacja: prawda - profesjonalizm w przestrzeni edukacyjnej uczelni posiada w pierwszym rzędzie znaczenie praktyczne, ponieważ pełna jest wewnętrznych napięć, sprzeczności, dynamicznych uwarunkowań oraz nieprzewidywalnych realiów, które trzeba permanentnie pokonywać, modyfikować i przezwyciężać ${ }^{45}$.

W kształceniu studentów - przyszłych nauczycieli muszą zadziałać czytelne normy, zasady, reguły, właściwa hierarchia wartości, które będą odniesieniem dla kształtowania zachowań tu, teraz społeczności akademickiej i w przyszłej pracy pedagogicznej studentów. Ilona Kość zwraca uwagę, że „Budowanie wzorców, formułowanie rekomendacji, wskazywanie dobrych praktyk - wszystko to ma na celu upowszechnianie etosu akademickiego jako punktu odniesienia dla wszelkich działań w środowisku akademickim" ${ }^{\prime 4}$.

Służba prawdzie przez nauczyciela akademickiego musi dwustronnie uwzględniać przymioty osoby ludzkiej: godność, rozumność-mądrość, wolność, odpowiedzialność, zdolność do miłości i transcendencji.

\begin{abstract}
The following considerations apply to the university setting. The aim of the presented study is to discuss the ways of searching for truth in academic work, and thus to show the areas of achieving this important, priority value in academic work. It is mainly concerned with the integration of the tasks of: an academic teacher and a pedagogy student on the plane of finding the truth: the search for it, discovery, and proclamation.
\end{abstract}

44 Ibidem, s. 395.

45 A.J. Sowiński, Wstęp, [w:] Edukacja akademicka..., s. 8.

46 I. Kość, Uniwersytet jako..., s. 96. 


\section{Bibliografia}

Chałas K., Dydaktyka akademicka w uniwersytecie katolickim, t. 1: Dydaktyka zaangażowana z doświadczeń Katedry Dydaktyki i Edukacji Szkolnej KUL, Wydawnictwo KUL, Lublin 2019.

Duma T., Prawda, [w:] K. Chałas, A. Maj (red.) Encyklopedia aksjologii pedagogicznej, Polwen Polskie Wydawnictwo Encyklopedyczne, Radom 2016.

Jan Paweł II, Encyklika Fides et Ratio, Wydawnictwo Znak, Kraków 1998.

Jan Paweł II, Homilia w czasie liturgii słowa skierowanego do środowiska Katolickiego Uniwersytetu Lubelskiego 1987, [w:] Jan Paweł II, Pielgrzymki do Ojczyzny - Przemówienia i homilie, Wydawnictwo Znak, Kraków 2005.

Jan Paweł II, Przemówienie do przedstawicieli nauki, [w:] Jan Paweł II, Pielgrzymki do Ojczyzny - Przemówienia i homilie, Wydawnictwo Znak, Kraków 2005.

Kość I., Uniwersytet, jako adwokat prawdy, [w:] A. Murarska, I. Kość (red.), Edukacja akademicka wobec prawdy, Wydawnictwo Naukowe Uniwersytetu Szczecińskiego, Szczecin 2010.

Milewski J., Prawda w metodzie dialogu stosowanej przez nauczyciela akademickiego, [w:] A. Murawska, I. Kość (red.), Edukacja akademicka wobec prawdy, Wydawnictwo Naukowe Uniwersytetu Szczecińskiego, Szczecin 2010.

Nowak M., Koncepcja prawdy a formy myślenia naukowego i badań naukowych, [w:] A. Murawska, I. Kość (red.), Edukacja akademicka wobec prawdy, Wydawnictwo Naukowe Uniwersytetu Szczecińskiego, Szczecin 2010.

Ostrowska U., Dylematy z zakresu kształcenia w szkole wyższej w aspekcie kształcenia, [w:] K. Jankowski, B. Sitarska, C. Tkaczuk (red.), Jakość kształcenia w szkole wyższej moda czy konieczność, Wydawnictwo Uczelniane Akademii Podlaskiej, Siedlce 2000.

Ostrowska U., Uczelnia wyższa, jako przestrzeń wartości na drodze do prawdy, [w:] A. Murawska, H. Kość (red.), Edukacja akademicka wobec prawdy, Wydawnictwo Naukowe Uniwersytetu Szczecińskiego, Szczecin 2010.

Palka S., Pedagogika w stanie tworzenia. Kontynuacje, Wydawnictwo Uniwersytetu Jagiellońskiego, Kraków 2003.

Pawluk D., Skowrońska D., Prawda-misja i wyzwanie dla współczesnego uniwersytetu, [w:] A. Murawska, I. Kość (red.), Edukacja akademicka wobec prawdy, Wydawnictwo Naukowe Uniwersytetu Szczecińskiego, Szczecin 2010. 
Prawda, [w:] Słownik współczesnego języka polskiego, t. 2, wyd. 2, Reader's Digest Przegląd, Warszawa 2001.

Rogalska-Morasińska A., Poszukiwanie prawdy o człowieku poprzez edukację międzykulturową. Ku profesjonalizacji zawodu nauczyciela, „Pedagogika Szkoły Wyższej” 2010, nr 32.

Starnawski W., Prawda podstawa wspólnoty, Wydawnictwo Salezjańskie, Warszawa 2005.

Stróżewski W., W kręgu wartości, Wydawnictwo Znak, Kraków 1992.

Tarnowski J., Jak wychowywać?, Wydawnictwo ATK, Warszawa 1993. 